The University of San Francisco

USF Scholarship: a digital repository @ Gleeson Library |

Geschke Center

Economics

College of Arts and Sciences

2007

\title{
The Effect of Social Capital on Group Loan Repayment: Evidence from Field Experiments
}

\author{
Alessandra Cassar \\ University of San Francisco, acassar@usfca.edu \\ Luke Crowley \\ Bruce Wydick \\ University of San Francisco, wydick@lucas.usfca.edu
}

Follow this and additional works at: http://repository.usfca.edu/econ

Part of the Economics Commons

\section{Recommended Citation}

Alessandra Cassar, Luke Crowley and Bruce Wydick. The effect of social capital on group loan repayment: evidence from field experiments. The Economic Journal. Volume 117, Issue 517, pages F85-F106, February 2007. DOI: 10.1111/

j.1468-0297.2007.02016.x

This Article is brought to you for free and open access by the College of Arts and Sciences at USF Scholarship: a digital repository @ Gleeson Library | Geschke Center. It has been accepted for inclusion in Economics by an authorized administrator of USF Scholarship: a digital repository @ Gleeson

Library| Geschke Center. For more information, please contact repository@usfca.edu. 


\title{
The Effect of Social Capital on Group Loan Repayment: Evidence from Field Experiments
}

\author{
For the Economic Journal Symposium on Joint-Liability Lending \\ JEL Classifications: O12, O16, C92, Z13
}

\author{
Alessandra Cassar, Lucas Crowley, and Bruce Wydick \\ Department of Economics \\ University of San Francisco \\ 2130 Fulton St. \\ San Francisco, CA 94117 \\ e-mail:acassar@usfca.edu,lucasmcrowley@yahoo.com,nydick@usfca.edu
}

March 2006

\begin{abstract}
An important question to microfinance is the relevance of existing social capital in target communities to the performance of group lending. This research presents evidence from field experiments in South Africa and Armenia, in which subjects participate in trust and microfinance games. We present evidence that personal trust between group members and peer homogeneity are more important to group loan repayment than general societal trust or acquaintanceship between members. We also find some evidence of reciprocity: those who have been helped by other group members in the past are more likely to contribute in the future.
\end{abstract}

The authors wish to thank Chris Wendell for outstanding help with data collection, conference organizers Niels Hermes and Robert Lensink along with Jana Vyrastekova, Chris Ahlin, Dan Friedman, Michael Jonas, Dean Karlan, Craig McIntosh, Stefan Klonner, Ashok Rai, Paul Ruud, and participants at the July 2005 Conference on Microfinance in Groningen, The Netherlands. Grant funding from the McCarthy Foundation is gratefully acknowledged. 


\section{Introduction}

During the past decade, exploring the role that social capital plays in economic behavior has emerged as one of the most fascinating and fertile areas of economic research. Although precise definitions of social capital are notoriously difficult to pin down, one of the early pioneers of the concept, James Coleman (1988), defines social capital as "social structure that facilitates certain actions of actors within the structure." In his definition, Coleman specifically highlights the roles of mutual obligation, expectations and trustworthiness, social norms, social sanctions, and the transmission of information.

Important studies in both developed and developing countries have analyzed the impact of social capital in economic relationships. Robert Putnam's celebrated work, Making Democracy Work: Civic Traditions in Modern Italy (1993) and Bowling Alone: America's Declining Social Capital (1995), brought attention to the role that social capital plays in the development of the modern state. Christopher Udry's ground-breaking (1994) work in Nigeria illustrated how the social capital existing in traditional societies may allow for more efficient credit contracts than in developed economies with weaker social capital.

This research uses experimental methods to estimate the importance of social capital to the success of group lending, a commonly used tool to deliver credit to the poor in developing countries. Although group lending has been shown to be correlated with higher portfolio quality in microfinance institutions (see, for example, Cull, Demirgüc, and Morduch in this feature), empirical work that has tried to isolate the influence of social capital on group loan repayment has faced a number of challenges. First, social capital and its various components are notoriously hard to measure. Moreover, groups often self-select over different components of social capital, thus making it endogenous to actual loan repayment. While some recent work, such as the articles in this feature by Ahlin and Townsend and by Karlan, has made important inroads in ameliorating these difficulties, our research investigates 
the influence of social capital using a different approach. We examine the effect of different components of relational social capital on group loan repayment by carrying out microfinance experiments on pools of subjects that reflect the characteristics of actual microloan recipients in Nyanga, South Africa and Berd, Armenia. In short, data from our experiments indicate that relational social capital in the form of personal trust between individuals and social homogeneity within groups has a positive effect on borrowing group performance. In contrast, we find that social capital as measured by simple acquaintanceship with other individuals or an individual's general trust in society via responses to the standard General Social Survey questions has little effect on group performance.

Economists have developed numerous theories that seek to explain the high repayment rates frequently associated with group lending in developing countries. These theories can be roughly divided into three categories: 1) those that view the relational aspects of social capital as central to the performance of group lending; 2) those that view the informational aspects of social capital as central to the performance of group lending; and 3) those that view the merits of group lending (relative to individual lending) solely through its innate properties as a joint-liability contract, where social capital plays little or no role. The distinction is important. If the first two groups of theories hold, the existing level of social capital in the form of strong personal relationships or local information may be critical to group lending's success. If the third group of theories holds, then group lending may succeed whether or not it is implemented among borrowers with high levels of existing social capital. Our experiments primarily seek to ascertain the influence of relational social capital on group performance, and the type of relational social capital that is most critical to it. However, we believe our results also may have implications for informational social capital since, in practice, borrowers use private information to self-select over aspects of relational social capital that may be conducive to the performance of their borrowing group. 
In borrowing groups with high levels of relational capital, strong social ties generate trust that other group members will contribute their share toward repaying group loans, thus making it worthwhile for each individual to repay. Moreover, because group members are jointly liable for repayment of the loan of each group member, they have an incentive to pressure fellow members who fail to maximize the probability that their own share of the group loan will be repaid. Ostensibly, the stronger the ties between group members, the greater the potential exists for social sanctions, and thus the more likely these sanctions are to lie off the equilibrium path, implying higher group loan repayment rates.

The most well-known paper in this category is that of Besley and Coate (1995), who argue that without the potential for social sanctions, group lending may offer little if any advantage over individual lending. However, given that sanctions are sufficiently strong, group lending in their model is able to curtail the moral hazard associated with loan repayment. Social sanctions, combined with peer monitoring also play a role in papers such as Stiglitz (1990), Besley, Banerjee and Guinnane (1993) and Armendáriz de Aghion (1999), though in focusing on peer monitoring, social sanctions are typically assumed to be exogenous. In the model of Wydick (2001), sanctions in the form of group expulsion are endogenous in that they represent a credible threat that comprises part of a perfect Bayesian equilibrium punishment strategy. Given a sufficiently low level of peer monitoring between borrowers, it is rational for group members to replace a defaulting member with a new member, even when there is no informational evidence of risky borrower behavior. In a high-information environment, expulsions and group replacements are only carried out if there is observable evidence of risky behavior. The threat of social sanctions over and above group expulsion, however, only adds to the incentive to undertake safe investments. While the threat of social sanctions can clearly discipline borrowers in many of these papers, it is often unclear if simple 
group expulsion, and the resulting loss of low-interest credit, is able to act as a strong substitute for social sanctions.

Papers in the second category focus on the heightened informational flows that exist in high social-capital areas, and their impact on group loan repayment. Foremost among these are papers by Van Tassel (1999) and Ghatak (1999) who both demonstrate that the borrower self-selection process used in most group lending schemes improves repayment rates through mitigating adverse selection in credit markets. If borrowers have clear information over the riskiness of one another's projects, they sort themselves into homogeneous groups through an assortative matching process. Van Tassel's model in particular shows how a lender can offer a set of individual and group loan contracts such that only high-ability borrowers will accept the group loan contract in equilibrium. The intuition is similar to the way insurance companies offer separate car insurance contracts to single and married drivers: Insurance companies know that married drivers tend to be safer, and that would be irrational to get married simply to pay less for car insurance. In Ghatak's model, risky borrowers internalize their externality on the group through being yoked with other risky borrowers. Safe borrowers are drawn back into the credit pool as the equilibrium interest rate is reduced, thus increasing repayment rates. In both models, existing social capital is important only in that it facilitates informational flow between borrowers; social sanctions are unnecessary to their results.

A third view of group lending downplays the influence of existing social capital in the performance of group lending altogether. The advantages of group lending over individual lending rest on neither the potential for social sanctions nor informational flows between members. Instead, the potential advantage of group lending arises simply from the terms of a joint liability contract. The best example of this view is Armendáriz de Aghion and Gollier (2000). They show that, in a pool of "safe" and "risky" borrowers, if the higher return realized by a risky borrower in the good state of nature is (uniquely) sufficient to cover for a defaulting 
group member, then the group lending contract can reduce the equilibrium interest rate and induce higher repayment rates relative to individual lending. The interesting point about their result is that unlike the models of Van Tassel and Ghatak, it does not rely on borrowers having an informational advantage over the lender. Their model is, however, sensitive to changes in assumptions about borrower returns.

Some empirical work has sought to discriminate between these three classes of group lending theories, but results have yielded mixed results. Wenner (1995) provides some evidence that active screening and social pressure among members of twenty-five Costa Rican credit groups improved group performance. Zeller (1998) finds credit group performance positively related to social cohesion within groups. Wydick (1999) finds that while peer monitoring appears to have some positive effect on group loan repayment, strong social ties within groups appears to make it more difficult to pressure fellow members to repay loans.

More recent research on larger microfinance data sets has yielded fascinating, but somewhat contradictory results on this question. Gómez and Santor (2003) use a statistical matching model to compare default rates of 1,389 individual and group borrowers in a Canadian lending institution. Based on observable variables, they find both selection and incentive effects to be operational in explaining lower default rates for group loans relative to individual loans. Moreover, incentive effects appear to be strengthened when "low trust" groups are removed from the sample, leaving groups within which there existed a higher degree of trust before applying for the loan. Their results, however, depend on the assumption that unobservable characteristics are uncorrelated with borrowing group formation. If borrowing groups admit members based on characteristics unobservable to the researcher, the results could overstate group-borrowing effects. Nevertheless, their findings present evidence in favor of the positive effects of informational and relational social capital on group loan repayment. 
The conclusions of Ahlin and Townsend (this feature) contrast somewhat with those of Gómez and Santor. Ahlin's and Townsends logit estimation results support the group selfselection models in the wealthier central region near Bangkok, and the models emphasizing the importance of social sanctions in the poorer, northeastern Thailand. Yet the fact that they find strong social ties within borrowing groups to be negatively correlated with group repayment causes them to challenge the idea that group lending works through its ability to harness all types of existing social capital. They argue that aspects of social capital that facilitate social penalties for non-repayment of group loans can be helpful to group lending, while social capital that inhibits social penalties can be harmful.

The particular angle that we take with our research is most similar to that of Abbink, Irlenbusch, and Renner (2002), Giné et. al. (2005), and Karlan (2005), who use experimental methods to analyze group lending repayment. We use the taxonomy developed by Harrison and List (2004) to categorize our own work within this body of experimental research.

Abbink et. al. carry out a conventional lab experiment in which students in the social sciences at the University of Erfurt participate in a microfinance game. Student subjects were formed into 31 borrowing groups of varying sizes; groups were rewarded with subsequent "loans" upon repayment of the previous loan. The game involves a stochastic element: Each student-borrower faces a $1 / 6$ probability of a negative shock, forcing her to depend on fellow members to repay the amount due on the group loan. The researchers are able to draw interesting conclusions about the effect of group size, gender, and social ties on loan repayment. To isolate the effect of social ties, they used two separate recruitment techniques. Some groups were formed of students registering individually for the experiment, minimizing the degree of social ties between members. Other participants registered together in groups; in these groups social ties were stronger. Some of their results are intriguing. Self-selected groups contributed mightily in the first round, but cooperation tended to fizzle among these 
groups in later rounds, while the cooperation of the randomly chosen groups started lower, but became more stable than the self-selected groups as the rounds progressed. Their results show that social ties within groups induce higher, but less stable, group loan repayment and that the performance of borrowing groups with initially weak social ties may grow with experience together in group loan repayment.

Giné et. al. (2005) carry out a framed field experiment in which subjects in central Lima received a "loan" of 100 points. A framed field experiment differs from an artefactual field experiment in that the experimenter attempts to replicate, or "frame" the experiment in the context of the actual task under study (in this case group, loan repayment). Subjects in their study had to invest their loan in either a safe project (yielding a certain return of 200 points) or risky project (yielding a return of 600 points with probability $1 / 2$ and zero otherwise). In their experiment the researchers introduce multiple rounds contingent on project success, jointliability, complete information on one's partner's project choice and outcome, communication between partners, and election of partners. The varying permutations allow the authors to identify the importance of dynamic incentives, insurance, monitoring, free-riding, and group formation, respectively. Taken together, Giné et. al. find evidence that group lending may actually induce moral hazard (through risk-taking and free-riding) rather than reduce it, though group self-selection counteracts some of these problems.

Karlan's (2005) research employs an artefactual field experiment, which he then links to observational data. An artefactual experiment differs from a conventional lab experiment in that it uses a non-standard subject pool that is pertinent to the issue being studied: Members of 41 female borrowing groups in a Peruvian microfinance program in Karlan's research replace the usual student subjects. He then tracks the behavior of these same subjects over the course of one year after they received real microfinance loans. Initially, experimenters had each of the subjects play the trust game in which either zero, 1, 2, or 3 coins are passed from 
player A to a partner, player B. If at least one coin was passed, the experimenters matched the contribution to player B, who could pass back as many coins as desired to player A.

Karlan finds that some characteristics related to cultural homogeneity such as both partners being indigenous, living nearby, and attending the same church are correlated with player A originally passing more coins, though social cohesion has a much weaker affect on the number of coins passed from B back to A. Over the course of the next year as borrowers repay their loans, the propensity for a borrower to pass coins in the role of player A is actually correlated with a lower level of savings and a higher rate of group expulsion/dropout. Karlan accounts for this result by noting that a higher propensity for a player A to pass coins may reflect a higher propensity to gamble rather than a higher propensity to trust. Additionally he finds that positive responses by borrowers to General Social Survey questions intended to measure social capital are negatively correlated with default and group dropout. Taken together, his results indicate moderate support for importance of existing social capital between members to group lending, but specifically the importance of innate trustworthiness, as opposed to trustworthiness driven by the fear of social sanctions.

Our research consists of both artefactual and framed field experiment components, in that we employ the trust game used by Karlan and the microfinance game of Abbink et. al. respectively. While Karlan's work was carried out among indigenous peoples of Western Hemisphere, we choose two very different locations: Nyanga, South Africa for a smaller pilot study and Berd, Armenia for our main study. As Ahlin and Townsend show in this feature, the relative effects of different joint-liability mechanisms may display considerable variation between clients and geographic regions. Thus we see it as advantageous to look for similarities and differences in the relationship between existing social ties and group loan repayment between substantially different subject pools and geographical areas. 
We favor the microfinance game developed by Abbink et. al. because it effectively captures the idea that group lending is heavily dependent on dynamic incentives. Individuals have an incentive to repay group loans if they believe a critical mass of other members will do the same, in order that they can receive future group loans. The belief that other members will contribute in the current round is partially a function of the social capital that exists within the borrowing group, which may be a product of a borrowing group member's (a) generalized trust in her society as a whole, (b) level of acquaintanceship with fellow group members, (c) specific trust toward group members, or (d) trust that emerges from early rounds of positive experience with other members in group loan repayment.

We use virtually the same experimental methodology among our smaller study in South Africa as we do in Armenia, though our questions to ascertain the level of social cohesion within microfinance game groups obviously needed to be distinct between sites. (E.g. there are no clans in Armenia, and no post-Perestroika generation in South Africa.) We use results from our trust games to obtain measures of trust and trustworthiness for our microfinance games. We also include measures of existing levels of trust and social capital between the subjects in our 36 microfinance game groups such as age, intensity of relationship, years members have known one another, whether a subject would be willing to lend another subject money, and distance between their homes. If our different measures of relational social capital within our exogenously formed borrowing groups are significantly associated with superior borrowing group performance in our experiments, then we would interpret this as evidence that these aspects of relational social capital may matter to real-world group loan repayment. To the extent that these measures of relational social capital are insignificantly related to borrowing group performance, we would take this as evidence that variability in borrowing group performance may be due to other factors which we do not account for in our 
experiments such as peer monitoring or contractual variations. We include results from both individual group member and group repayment decisions.

Our results indicate first that specific trust between a borrower and other individual group members appears to be relatively more important than trust in society as a whole for group loan repayment. This holds true for our subjects in both South Africa and Armenia. We find that group loan repayment appears to be more heavily associated with affirmative answers to questions such as, "Would you lend (person $x$ ) 1000 drams?" than questions from the General Social Survey intended to measure broadly existing trust in society. Second, we find moderate evidence that social homogeneity in borrowing groups may be helpful. Having a larger number of one's own clan as members in the group spurred individual contributions in South Africa, while having a high number and homogeneous makeup of long-term local residents facilitated group repayment in Armenia. Third, we find mere acquaintanceship between members to be unrelated to group performance. Since social sanctions are generally ineffectual without at least weak social ties between individuals, our study suggests that potential social sanctions may not be the most important component of relational social capital to influence group loan repayment; interpersonal trust appears to be more important.

We also find that when group repayment begins to break down from random shocks or non-contribution, individuals withhold their own contributions, apparently to avoid getting burned by contributing to a losing cause. But our results also reveal evidence of reciprocity: When a member experiencing a negative shock is helped by others to repay the group loan, the benefiting member is more likely to contribute in the subsequent round.

The remainder of our paper is organized as follows: Section 2 provides details of our experimental methodology in Nyanga and Berd. Section 3 presents and discusses results from our experimental data. Section 4 concludes with a summary of how our results compare with those of the existing empirical literature. 


\section{Experimental Design}

\section{Locations}

We conducted a smaller, pilot experiment at the $\mathrm{SHAWCO}^{1}$ Senior Centre in Nyanga, Cape Town, South Africa, pop. 24,003. Nyanga is a poor town, made up of nearly all black residents, and where annual per capita income is approximately 30,553 rand (US\$4,460) (Republic of South Africa 2003 National Census). The HIV prevalence rate in Nyanga is one of the highest in the area. The subjects were identified by the neighborhood representatives of the local municipality and experienced SHAWCO staff as women who fit the profile of the typical microcredit borrower in the region: eighteen years of age and older, either employed or available for work ${ }^{2}$, and willing to participate in the experiment that took place from June 10th to July 10th, 2004. From the pool of potential subjects, a systematic sampling took place whereby a subject fitting the profile from every fifth eligible household was selected to participate.

We conducted our second, larger experiment at the Artig Business Company (ABC) in Berd, Tavush Marz, Armenia (pop. 8,700), with per capita income 1,830,000 drams (US\$3,900), roughly comparable to Nyanga. The subjects were identified by the ABC using the same criteria established above, with the experimental period lasting from March $19^{\text {th }}$ to April $6^{\text {th }}, 2005$. In both experiments, any women who had a previous professional relation with either the SHAWCO in Nyanga or the ABC in Armenia or who had ever been part of a joint-liability borrowing group were excluded from the subject pool. In Nyanga, 87 women completed the general survey, 62 of them participated in the trust game experiment, and 60 participated in the microfinance experiment. ${ }^{3}$ In Berd, 160 women completed the general

\footnotetext{
${ }^{1}$ Student Health and Welfare Committee, a student run NGO sponsored by the University of Cape Town.

${ }^{2}$ The definition of "available for work" considered whether the potential subject could participate in the Masizikhulise Project.

${ }^{3}$ Tests on self-selection into the game in Nyanga revealed those who opted to participate in the microfinance game tended to be slightly poorer, were somewhat more religious, and somewhat more politically inclined.
} 
survey and participated in the trust game experiment, and 156 of them participated in the microfinance experiment.

Survey

In the Nyanga experiment, the subjects filled out a 38-question survey, which took approximately fifteen to twenty minutes to complete. The survey contained demographic questions such as age, length of residency, spoken languages, clan name as well as questions related to the various affiliations of the subject, her level of participation in groups and associations (e.g. political organizations, churches, ROSCAS, etc.).

In Berd, the subjects filled out a 26-question survey that also required about fifteen to twenty minutes to complete. ${ }^{4}$ In addition to questions related to demographic characteristics and the subject's involvement in society, the Berd questionnaire included three attitudinal questions from the General Social Survey (GSS) that relate to trust (also used in Karlan, 2005). ${ }^{5}$ The subjects were guaranteed a minimum of 1,500 drams upon completion of the survey and the two follow-up activities with final payment depending on the outcomes of the games. (We were careful not to mention the word "game" or "play" in favor of the more neutral terms "activity" and "decision making").

After completing the surveys, the subjects participated in the trust game and microfinance game experiments. In Berd we alternated the order in which the experiments were played to account for the possible dependence of one game's results from the results of the game previously played.

\footnotetext{
${ }^{4}$ Both the Berd and Nyanga surveys are available at http://www.usfca.edu/fac-staff/acassar.

${ }^{5}$ The three GSS questions we used were the commonly administered trust question, "Generally speaking, would you say that most people can be trusted or that you can't be to careful in dealing with people?", the question on fairness, "Do you think most people would try to take advantage of you if they got the chance, or would they try to be fair?", and the question on helpfulness, "Would you say that most of the time people try to be helpful, or that they are mostly just looking out for themselves?".
} 


\section{Trust Game}

As in the original trust game design of Berg, Dickhaut, and McCabe (1995), pairs of individuals are randomly matched and assigned the role of either "sender" or "receiver." In the Berd experiment, our largest subject pool, we ran two kinds of treatments: a treatment with equal initial endowments (senders and receivers starting with 1,000 drams), as well as a treatment with unequal endowments (senders starting with 1,000 drams and receivers starting with 400 drams). In Nyanga we ran only the unequal starting endowment treatment with senders starting with 25 rand and receivers starting with 10 rand. We used the treatment with unequal endowments because it more closely represents an actual microfinance situation in which both initial assets and returns are seldom equal between members, as well as to explore fairness issues in the trust game.

The trust game consists of two stages. In the first stage, the sender has to choose how much of the initial endowment to send to the receiver (the ratio of the amount sent to the initial endowment is considered a measure of trust). The amount sent is then multiplied by three by the experimenter and passed to the receiver. In the second stage, the receiver then has the opportunity to return some of the received amount back to the sender (the ratio of the amount returned to the amount received is considered a measure of trustworthiness).

In Berd, approximately two weeks after completing the general survey, twelve groups of ten to eighteen subjects, were formed and allocated to the different games, depending on whether they were chosen to play the trust game before or after participating in the microfinance game. In addition, as we explain below, we did control for whether the subjects began their professional lives before (or during) perestroika or post-perestroika. The reading of the instructions occurred in front of the entire group. During the actual playing of the game, the pairings remained anonymous. 
In Nyanga, the trust game experiments were played between pairs of individuals from opposite sides of town with no previous level of social connection. Approximately one week after completing the general survey, six groups of fourteen to eighteen subjects were randomly formed and over the course of four days were called to the SHAWCO Senior Center. As in Glaeser, Laibson, Scheinkman, and Soutter (2000), the subjects saw with whom they were matched but we ensured that they had never met one another before the game to control for the effect of personal social connectedness on trust behavior. Individuals who arrived together or talked with each other were not paired together; otherwise, they were paired so as to maximize the physical distance between their households and, therefore, to minimize the chances that they had a personal relationship (corroborated by an exit interview). The pairings were not made public before the reading of the instructions. ${ }^{6}$ The subjects were then divided into two groups, senders and receivers. One pair at a time, they proceeded into a different room where a second experimenter ran the trust game experiment and administered the exit questionnaire. Summary results from the trust games are given in the appendix in Table A-1. Microfinance Game

The microfinance experiment follows Abbink et. al. (2002), with some minor modifications. A group of six individuals receive a loan of 30 rand (3,000 drams in Berd), for which all group members are jointly liable for repayment. The loan enables each member of the group to invest 5 rand (500 drams) in an individual risky project. All projects are of the same type and the probability of success is 5/6. In the event of a successful project, the investor receives a project payoff of 12 rand (1200 drams). If the project fails, however, the subject receives zero.

After the outcomes of the projects are realized, the group loan plus interest must be repaid. We assumed a group loan interest rate of $20 \%$, so that the group is liable to repay a total amount of 36 rand (3600 drams). The individuals whose project failed cannot contribute

\footnotetext{
${ }^{6}$ Instructions for all experiments are available at http://www.usfca.edu/fac-staff/acassar.
} 
to group loan repayment, so the group debt is split among those individuals whose projects succeed and decide to contribute. Information on the individual project's success or failure is private so that no other member of the group can ascertain whether a group partner's defaults are due to project failure or strategic decision-making. In this environment, loan repayment ensues in the absence of contract enforceability.

Since the debt is evenly divided among those individuals who are both able and willing to contribute, the fewer the number of contributors, the higher their burden. Since contributions can only be financed from the current project payoffs, full repayment is only possible if at least half of the group members (three subjects) decide to contribute. At the end of the round, the players are informed about the number of contributors, but not their identities, and their resulting payoff (one's project payoff minus own share of repayment). If the group fulfils its repayment obligation, the game continues into a further round, which proceeds in the same way with the same group members. If more than half the group members default, regardless of whether the default is strategic or due to project failure, then the group cannot repay the full amount, and no further rounds are played. We like this feature of the game because it replicates the dynamic incentives utilized by most microfinance institutions, which make follow-up loans conditional on the full repayment of previous loans.

One aspect of the experiment of Abbink et. al. has been questioned by some researchers (for example Morduch and Armendáriz de Aghion, 2005), namely that the results of the experiment are more difficult to interpret because participants are told that it will consist of a finite number of rounds (ten), leading to the traditional unraveling problem in which non-contribution in all rounds is a subgame-perfect equilibrium. We consequently modify their experiment slightly by creating, after the sixth round, a $1 / 6$ probability that a group continues for another round. To minimize contamination from subjects taking into 
account an impending end-game, we utilize data from rounds one to six in our analysis. (Our fundamental results are unchanged by excluding the small amount of data from later rounds.)

To most efficiently isolate the effect of social capital on group performance, the microfinance game groups were formed so as to maximize the number of group members who shared the same clan name in Nyanga. To carry out tests for social homogeneity within groups, some groups were "stacked" with individuals who shared the same clan name, which were made public during pre-game introductions; otherwise, they were randomly formed. The microfinance experiments were played about one week after the trust game experiments.

In the Berd experiment, one-third of the microfinance groups were formed by those who began their working lives before or during perestroika, one-third by individuals who began their working lives post-perestroika, and one-third was mixed (we used a cut-off age of 36 to identify this). The experiments were played either one week before the trust games or one week after, depending on the subject pool. Subjects knew who belonged to their microfinance group in order to test for the effect of heterogeneity on repayment.

\section{Empirical Results}

We perform estimations on two separate units of observation. First, we look at the repayment behavior of individuals in the microfinance games as a function of (a) negative shocks to themselves and the other five group members; (b) contributions by other members; (c) measures of acquaintanceship and personal trust level between the given individual and other members in the group; (d) measures of generalized trust by the given individual in the society and culture around them; (e) results from the trust game; and (f) social/cultural group homogeneity between the individual member and other group members. (Means and standard deviations of our independent variables are provided in Table 1.)

Ideally for our type of unbalanced panel data, one would like to employ fixed or random effects estimation. However, the time-invariant nature of most of the important 
variables in our study precludes fixed-effect estimation. We carried out a Hausman test for the feasibility of a random effects estimator (which can be used on time-invariant data) vis-à-vis fixed effects on our four time-variant variables, but the Hausman test rejected the null hypothesis of exogeneity of these right-hand-side variables at the $1 \%$ level. Instead, we run OLS on the average contribution of each individual for every round in which the borrower was able to contribute to group repayment (experienced no shock), the only weakness with this approach being possible path dependence in the denominator of the dependent variable. We report these estimations for our pilot study in Nyanga and our larger study in Berd in Table 3. To act as a check on these estimations for our principal study in Berd, we employ a logit estimation on our pooled, unbalanced panel data in Table 4, being aware that such an estimation does overweight the frequency of individuals in the sample from groups with longer duration. We therefore employ an additional check on these estimations, which is also included in Table 4, a logit estimation on individual rounds in Berd, for which there is no doubt of pure exogeneity or sample bias, but where estimations are performed on a sequence of smaller samples. To respect space constraints, we include rounds 2 through 5 , before most groups had ceased repayment; the estimations on later rounds yield little additional insight, but are available upon request. Fortunately, we find remarkable consistency from our three types of estimations on individual repayment.

Next, we examine the repayment behavior at the borrowing group level using means and aggregates of many of these variables for each group of six borrowers. We present the results in Table 5, where we first show estimations for the 26 microfinance game groups in Berd. The dependent variable is the number of rounds of borrowing group survival, upon which we carry out OLS estimations. Summaries of group longevity and contribution rates in Berd and Nyanga are in Table 2. In this table we also present some estimations where we combine the Berd-Nyanga data set of 36 groups. For both Nyanga and Berd we created 
measures of group heterogeneity along the lines of what seems to be the most important cultural divisions in the respective societies. In Nyanga the greatest cultural distinction seems to fall along the lines of clan membership. But in Berd, due to the tremendous changes in post-Soviet society, the greatest social and cultural division there is not ethnic, but generational. Those who began work after Perestroika possess an economic and cultural outlook that is unusually distinct from that of the older generation. Along these lines we created statistically comparable indices of heterogeneity for our 36 borrowing groups, 10 in Nyanga and 26 in Berd. While the differences in heterogeneity are obviously quite distinct (ethnic vs. generational), we think it worthwhile to examine some aggregated measure of heterogeneity across our two study areas. We also examine heterogeneity in groups between "insiders" and "outsiders", creating an index that is more heterogeneous (homogeneous) if the group contains a larger (smaller) variation of long-term residents and newcomers as measured by the standard deviation in the number of years of members' local residency. We summarize our results below and juxtapose them to those of related empirical literature when appropriate comparisons can be made:

(a) Shocks

To no surprise, the results show that negative random shocks impact both individual and group repayment. In our Berd estimations we found individual repayment to be higher when a member had received a shock the period before (implying other members had covered for her). Repayment also increased as a function of the total number of shocks in the OLS estimations (recalling that our reference for individual repayment includes those rounds only in which she did not receive a negative shock). We interpret this as evidence of reciprocity among our subjects: As an individual has been helped by other group members, she is more likely to contribute given the opportunity the next time. The effect is large and statistically significant at the $1 \%$ level. For every additional negative shock received, it increases the fraction of times she contributes on average somewhere between 0.30 and 0.40 , depending on our specification. 
This finding supports a large theoretical literature on the prevalence and importance of reciprocity among similar populations pioneered by Scott (1976) and Fafchamps (1992).

Shocks to other members have a negative effect on individual contributions, which is statistically significant in Nyanga. It appears that when players sense that the end of the game is impending due to a lack of contributions by other members, this causes the individual to want to avoid being the "sucker" who contributes futilely in the last round. In the group estimations in Table 5, we see that an increase in the mean number of shocks per round by one reduces the number of rounds the borrowing group continues to receive loans by about 1.7 .

(b) Effect of Others' Contributions

Theory would posit that the contributions of other group members could have differential effects: Contributions by other members could generate peer effects or fairness effects that stimulate one's own contribution, or it could provoke free-rider problems. In Berd we find very modest evidence that the contributions of others in the prior period increase one's own desire to contribute in the following period. While none of the coefficients is significant, the variable consistently carries a positive sign on repayment in every specification. (c) Personal Trust

Our principal measure of personal trust is the question, "Would you lend (person $x$ ) 1000 drams (100 rand)?” Answering yes to this question for increasing numbers of individuals in the group has a positive effect on both individual contributions and group longevity. The coefficient carries the (correct) positive sign in virtually all of the estimations, and is statistically significant at the $1 \%$ level in our most important estimation on the entire sample in Table 4. These results would seem to be consistent with Abbink et. al. (2002) who find that randomly formed groups perform less well than self-selected groups of friends, among which a greater level of trust presumably exists. 
We interpret these results on personal trust as some evidence for the importance of screening and self-selection in borrowing groups; personal trust appears to play a far more important role than simple acquaintanceship. Mere acquaintanceship with other individuals in the group before the experiment ("Do you know person $x$ ?) is insignificant in virtually all of the estimations, and negatively significant in round 5 in Table 4. The implication is that group lending may not be successful when people simply know one another well; it is more likely to succeed where people can choose among a large number of trustworthy group members. Moreover, the data show distance between members' homes to be (surprisingly) positively related to group performance. To the extent that someone needs to know another individual, or at least know of her and live somewhat close to her to impose some type of social sanction in response to suspected defections in the game, our results offer little support to Besley and Coate's (1995) hypothesis that the potential for social sanctions is vital to group lending. Trust that others will contribute their share is far more significant in our study.

(d) Generalized Trust

While generalized trust in society is likely to be integral at a broader level, such as in the establishment of institutions and governance structures, positive answers to the General Social Survey questions proved to be insignificant as a determinant of behavior in the microfinance game, and often carry an unexpected sign. This is consistent with the results of Frey and Bohnet (1999), who find that an accurate portrayal of cooperative behavior is only revealed when "social distance" diminishes and subjects interact with an identifiable person. Our finding contrasts somewhat in this respect with Karlan (2005) who finds that the GSS survey questions relative to societal trust were negatively associated with default among his sample of Peruvian microfinance borrowers. It is difficult to explain the insignificance of social capital reflected in the GSS questions, other than by noting that this fits a pattern in our empirical results. This pattern clearly points to the relative importance for group lending of personalized trust over generalized trust in society, and that answers to specific, contextual questions, such as "Would you lend (person $x) 1000$ drams (100 rand)?" are a more powerful 
indicator of behavior than generalized questions. Thus, if group members have an interest in being members of well-functioning groups, then self-selection should create endogenously formed groups with a high level of specific trust among members. Because self-selection relies on specific trust and not general trust, our results would suggest that self-selected groups should function better. This result appears consistent with what Ahlin and Townsend (this feature) find on the importance of self-selection and screening among their borrowers in central Thailand.

(e) Effect of Trust Game Results

We use our trust game to generate measures of both trust and trustworthiness that may be useful in understanding behavior in our microfinance game. In short, consistent with Karlan (2005), in our experiment, we uncovered no evidence that trusting behavior is at all positively related to greater rates of contribution to group loans. (He actually finds that it is negatively related, and interprets the result as possibly due to risk-loving behavior.)

We find some evidence that trustworthiness is related to contributions, an effect that is fairly substantial in the Berd estimations: If a receiver returned all of the coins passed to him in the trust game, it increases his probability of contribution in the microfinance game by about 40 percentage points. Thus, a subject who was trustworthy as a receiver in the trust game tended to be a strong contributor in the microfinance game. Since players were anonymous in the trust game, the significance of the trustworthiness variable may reflect borrower quality or dependability, meaning that a community of dependable people may be likely to be a community of well-performing borrowing groups. However, the coefficient on trustworthiness was insignificant in Nyanga and in the group estimations.

\section{(f) Social Homogeneity}

Many researchers and development practitioners have believed for some time that social cohesion has played a major role in credit group performance. Empirical evidence from actual field data has been mixed on the question with some such as Zeller (1998) finding positive effects of a variable counting the number of common characteristics among members. 
Karlan (2005) finds that ethnically homogeneous pairs are more trusting in the Peruvian experiments. Other results, such as Wydick (1999), find that the stronger social ties between members, the less credible the threat of social sanctions becomes. Alin and Townsend (this feature) also find evidence that existing social ties may hinder group loan repayment.

The results from our field experiments lend measured empirical support to the idea that social homogeneity is a good thing for group loan repayment. In Nyanga, individual contributions are significantly associated at the $95 \%$ level with the number of members from the same clan in the group, as seen in Table 3. Although two very different kinds of social heterogeneity characterize Nyanga and Berd, for the combined estimations in Table 5 we use a common diversity index of similar/dissimilar members (by clan and pre-and post Perestroika) and find the point estimate showing heterogeneity to have negative effects, but statistically insignificant. Table 5 also shows heterogeneity in groups as measured by long-term vs. shortterm residents. The coefficient on the standard deviation of number of years residing in the local area has the expected sign, and is significant at the 99\% level in Berd and at the 95\% level in the combined estimations. Taken in light of other research, our results support the idea that social and cultural group homogeneity is likely to exert a positive influence on loan repayment.

\section{Conclusion}

Researchers face a puzzle in disentangling the diverse aspects of social capital and their influence on borrower behavior in joint-liability loan contracts. We view our experimental results as one piece to this puzzle. In contrast to other work, including the other work in this feature, we employ artefactual and framed field experiments that allow us to work at the problem from a particular angle through imposing a maximum degree of exogeneity on our estimations, while using subjects who closely represent the population of individuals that actually receives group loans in developing countries. We view this kind of experimental work relative to other techniques, such as estimations on field data, not as substitutes, but instead as complements in this puzzle-solving process. Our goal for this research, and its contribution to this feature, is that it be part of an effort that collectively triangulates on a better understanding 
of group lending. In this sense we cannot claim general inference from our findings, but instead that our results be viewed in light of the wide array of empirical methodologies focused on the same question. Taken in this context, it is interesting that our results support many of the traditional beliefs about group lending and work from other types of empirical studies.

At the outset of this paper we divided theories about group lending into three categories: those that emphasize the importance of relational social capital to group lending, those that emphasize the importance of informational social capital, and those that emphasize the inherent contractual benefits of joint-liability contracts. That we find socially heterogeneous groups consistently performing worse than socially homogeneous groups supports the notion that relational social capital matters to group lending. Social homogeneity appears to facilitate a confidence that other members will indeed repay, augmenting the belief that the group is likely to receive subsequent loans in the future, and that those who do repay in early rounds won't get burned by non-repayers. We also find evidence of reciprocity within groups as group members who have realized more shocks (and relied on others to pay for them in the past) are more likely to repay the next time they have the opportunity. Thus we find that social capital appears to grow with positive experiences from other members following through with repayment in the group.

Additionally, we believe that our finding that personal trust between specific pairs of group members significantly affects performance in our microfinance games is significant. First, it implies that group lending is likely to be more successful when a borrower faces a pool of potential borrowing partners that contains a large number of people whom she personally trusts. Moreover, to the extent that borrowers have a choice within this pool, it supports the notion that informational social capital in the process of group self-selection and screening is likely to matter in group lending. Although in our experiments borrowing groups are formed exogenously, if personal trust matters to group performance in practice, then borrowers will have an incentive to self-select over this variable. 
In contrast, we find traditional measures of general, society-wide social capital, such as reflected by the commonly used GSS questions to be mostly insignificant. In many respects, this result is unsurprising: Repayment under dynamic incentives is individually rational when group members believe that the group as a whole will perform well enough to continue receiving future loans. This should depend on the confidence that borrowers have in the particular individuals within the borrowing group far more than their confidence in society generally. That we find the strength of acquaintanceship between members and the distance between their homes to be insignificantly (and in some specifications negatively) related to group performance would seem to imply that the most important component of relational capital may be interpersonal trust between members rather than the underlying threat of social sanctions for non-contribution.

One caveat to our findings and those from similar research based on field data is that a high degree of social capital between group members is probably insufficient in and of itself to generate high repayment rates. For example, the relative importance of within-group social capital in preventing defaults may well be weaker than the mere threat of group expulsion, the availability of alternative credit, or the intensity and quality of loan officer activity. As shown in Cull, Demirgüç-Kunt, and Morduch (this issue), other institutional factors matter greatly to borrower performance and the performance of microfinance institutions generally, such as investments in quality loan officers and other staff. There is probably no single factor that is alone responsible for the frequent success with group lending in so many areas of the developing world, but this research suggests that relational social capital between members appears to be one significant factor in this success. 


\section{References}

Abbink, Klaus, Bernd Irlenbusch, and Elke Renner (2002), 'Group size and social ties in microfinance institutions' Univ. of Nottingham and Univ. Erfurt Working Paper.

Ahlin and Townsend (2006), 'Using repayment data to test across models of joint liability lending,' Economic Journal, current issue.

Armendáriz de Aghion, Beatriz (1999), 'On the design of a credit agreement with peer monitoring,' Journal of Development Economics, vol. 60, no.1, pp.79-104.

Armendáriz de Aghion, Beatriz and Christian Gollier (2000), 'Peer group formation in an adverse selection model’ Economic Journal, vol. 110, pp.632-643.

Armendáriz de Aghion, Beatriz and Jonathon Morduch (2005) The Economics of Microfinance Cambridge: MIT Press.

Berg, Joyce, John Dickhaut, and Kevin McCabe (1995), 'Trust, reciprocity, and social history' Games and Economic Behavior, vol. 10, no.1, pp.122-142.

Besley, Timothy and Steven Coate (1995), 'Group lending, repayment incentives and social collateral,' Journal of Development Economics, vol. 46 (1), pp. 1-18.

Banerjee, Abhijit, Timothy Besley, and Timothy Guinnane (1994), 'Thy neighbor's keeper: design of a credit cooperative with theory and a test,' Quarterly Journal of Economics, vol. 102 (9), pp. 491-515.

Coleman, James (1988) "Social capital in the creation of human capital" American Journal of Sociology, vol. 94, pp.95-120.

Cull, Robert, Asli Demirgüc-Kunt, and Joonathan Morduch (2006) 'Financial performance and outreach: a global analysis of leading micro banks,' Economic Journal, current issue.

Fafchamps, Marcel (1992) 'Solitary networks in preindustrial societies: rational peasants with a moral economy' Economic Development and Cultural Change, vol.40, pp.147-174.

Bohnet, Iris and Bruno S. Frey "Social Distance and other-regarding behavior in dictator games: Comment” The American Economic Review, vol. 89 (1), pp. 335-339.

Ghatak, Maitreesh (1999), 'Group lending, local information and peer selection,' Journal of Development Economics, vol. 60 (1), pp.27-50.

Giné, Xavier, Pamela Jakiela, Dean Karlan, and Jonathan Murdoch (2005), "Microfinance games" Working Paper.

Glaeser, Laibson, Scheinkman, and Soutter (2000), 'Measuring trust,' Quarterly Journal of Economics, vol. 115, pp.811-846.

Gómez and Santor (2003), 'Do peer group members outperform individual borrowers? a test of peer group lending using canadian microcredit data,' Bank of Canada Working Paper (October).

Harrison, Glenn W. and John A. List (2004), 'Field experiments,' Journal of Economic Literature, vol. 62 (December) pp.1009-1055.

Karlan, Dean (2005), 'Using experimental economics to measure social capital and predict financial decisions,' American Economic Review (forthcoming).

Karlan, Dean (2006), 'Social connections and group banking,' Economic Journal, current issue

Putnam, Robert. D. (1993), Making Democracy Work: Civic Traditions in Modern Italy, Princeton University Press, Princeton, NJ. 
Putnam, Robert. D. (1995), 'Bowling alone: America's declining social capital,' Journal of Democracy, vol. 6, pp. 65-78.

Scott, James, The Moral Economy of the Peasant, New Haven: Yale Univ. Press (1976).

Stiglitz, Joseph (1990), 'Peer monitoring and credit markets,' The World Bank Economic Review, vol. 4 (3), pp.351-366.

Udry, Christopher (1994), 'Risk and insurance in a rural credit market: an empirical investigation in northern Nigeria,' Review of Economic Studies, vol. 61 (1), pp.495-526.

Van Tassel, Eric (1999), 'Group lending under asymmetric information,' Journal of Development Economics, vol. 60 (1), pp.3-25.

Wenner, Mark (1995), 'Group credit: a means to improve information transfer and loan repayment performance,' Journal of Development Studies, vol. 32 (1), pp. 263-281.

Wydick, Bruce (1999), 'Can social cohesion be harnessed to mitigate market failures? evidence from group lending in Guatemala,' Economic Journal, vol. 109 pp.463-75.

Wydick, Bruce (2001), 'Group lending under dynamic incentives as a borrower discipline device,' Review of Development Economics, vol. 5 (3), pp.406-420.

Zeller, Manfred (1998), 'Determinants of repayment performance in credit groups: the role of program design, intragroup risk pooling, and social cohesion,' Economic Development and Cultural Change, vol. 46 (3), pp. 599-620. 


\section{Table 1: Summary Statistics}

\begin{tabular}{|c|c|c|c|c|}
\hline $\begin{array}{l}\text { Group Repayment } \\
\text { Variables: }\end{array}$ & $\begin{array}{c}\text { Berd, } \\
\text { Armenia } \\
\overline{\mathbf{X}}, \sigma\end{array}$ & $\begin{array}{c}\text { Nyanga, } \\
\text { South Africa } \\
\overline{\mathbf{X}}, \sigma\end{array}$ & $\begin{array}{c}\text { Individual } \\
\text { Repayment } \\
\text { Variables: }\end{array}$ & $\begin{array}{c}\text { Berd, } \\
\text { Armenia } \\
\overline{\mathbf{X}}, \sigma\end{array}$ \\
\hline No. Observations & $\mathrm{n}=26$ & $\mathrm{n}=10$ & No. Observations & $\mathrm{n}=498$ \\
\hline $\begin{array}{l}\text { Number of Rounds } \\
\text { Reached by Group }\end{array}$ & $\begin{array}{c}4.192 \\
(1.650)\end{array}$ & $\begin{array}{c}3.000 \\
(1.563)\end{array}$ & $\begin{array}{l}\text { Subject Contributes } \\
\text { in Round }\end{array}$ & $\begin{array}{l}0.731 \\
(0.444)\end{array}$ \\
\hline $\begin{array}{l}\text { Mean Per Period } \\
\text { Shocks } \\
\text { Received by Group }\end{array}$ & $\begin{array}{l}1.119 \\
(0.678)\end{array}$ & $\begin{array}{l}1.358 \\
(0.416)\end{array}$ & $\begin{array}{l}\text { Shock to Subject } \\
\text { Period Before }\end{array}$ & $\begin{array}{l}0.143 \\
(0.350)\end{array}$ \\
\hline $\begin{array}{l}\text { Mean Number of } \\
\text { Others Acquaintances } \\
\text { in Group }\end{array}$ & $\begin{array}{l}1.489 \\
(1.033)\end{array}$ & $\begin{array}{l}0.733 \\
(0.424)\end{array}$ & $\begin{array}{l}\text { Shocks to Others in } \\
\text { Group } \\
\text { Period Before }\end{array}$ & $\begin{array}{l}0.713 \\
(0.800)\end{array}$ \\
\hline $\begin{array}{l}\text { Mean Number Others } \\
\text { Would Loan to in } \\
\text { Group }\end{array}$ & $\begin{array}{l}1.590 \\
(0.849)\end{array}$ & $\begin{array}{c}0.450 \\
(0.385)\end{array}$ & $\begin{array}{l}\text { Contrib. by Others } \\
\text { in Group - Period } \\
\text { Before (Dram) }\end{array}$ & $\begin{array}{l}3000.00 \\
(416.94)\end{array}$ \\
\hline $\begin{array}{l}\text { Mean Distance, } \mathrm{km} \\
\mathrm{b} / \mathrm{t} \text { Members' Homes }\end{array}$ & $\begin{array}{l}26.727 \\
(5.428)\end{array}$ & $\begin{array}{l}10.851 \\
(1.705)\end{array}$ & $\begin{array}{l}\text { Num. of Acquaintances } \\
\text { in Group }\end{array}$ & $\begin{array}{c}1.382 \\
(1.318)\end{array}$ \\
\hline $\begin{array}{l}\text { Mean Fraction of Life } \\
\text { Lived in Area }\end{array}$ & $\begin{array}{c}17.867 \\
(13.114)\end{array}$ & $\begin{array}{l}2.427 \\
(0.383)\end{array}$ & $\begin{array}{l}\text { Num. of Group } \\
\text { Members Subject } \\
\text { Would Loan to }\end{array}$ & $\begin{array}{l}1.677 \\
(1.753)\end{array}$ \\
\hline $\begin{array}{l}\text { Heterogeneity-Fraction } \\
\text { Life Lived in Area }\end{array}$ & $\begin{array}{c}0.243 \\
(0.129)\end{array}$ & $\begin{array}{c}0.750 \\
(0.339)\end{array}$ & $\begin{array}{l}\text { Mean Distance } \\
\text { to Others' Homes }\end{array}$ & $\begin{array}{l}26.668 \\
(8.028)\end{array}$ \\
\hline $\begin{array}{l}\text { Percent Members } \\
\text { Work After } \\
\text { Perestroika/Same Clan }\end{array}$ & $\begin{array}{c}0.587 \\
(0.3589)\end{array}$ & $\begin{array}{c}0.400 \\
(0.378)\end{array}$ & $\begin{array}{l}\text { Fraction of Life } \\
\text { Lived in Area }\end{array}$ & $\begin{array}{l}0.1684 \\
(0.266)\end{array}$ \\
\hline $\begin{array}{l}\text { Heterogeneity in } \\
\text { Peer Group/Clan, } \\
\text { (given by std.dev.) }\end{array}$ & $\begin{array}{l}0.298 \\
(0.243)\end{array}$ & $\begin{array}{c}0.477 \\
(0.402)\end{array}$ & $\begin{array}{l}\text { Fraction of Others } \\
\text { in Peer Group }\end{array}$ & $\begin{array}{l}0.752 \\
(0.250)\end{array}$ \\
\hline Sender Trust & $\begin{array}{c}0.428 \\
(0.158)\end{array}$ & $\begin{array}{c}0.334 \\
(0.103)\end{array}$ & $\begin{array}{l}\text { Sender Trust } \\
\text { (Only Senders) }\end{array}$ & $\begin{array}{c}0.431 \\
(0.246)\end{array}$ \\
\hline $\begin{array}{l}\text { Receiver } \\
\text { Trustworthiness }\end{array}$ & $\begin{array}{l}0.437 \\
(0.140)\end{array}$ & $\begin{array}{l}0.360 \\
(0.192)\end{array}$ & $\begin{array}{l}\text { Receiver } \\
\text { Trustworthiness } \\
\text { (Only Receivers) }\end{array}$ & $\begin{array}{l}0.441 \\
(0.228)\end{array}$ \\
\hline $\begin{array}{l}\text { GSS\#1: } \\
\text { Trust Question }\end{array}$ & $\begin{array}{c}0.660 \\
(0.200)\end{array}$ & & $\begin{array}{l}\text { GSS\#1: } \\
\text { Trust Question }\end{array}$ & $\begin{array}{c}0.637 \\
(0.481)\end{array}$ \\
\hline $\begin{array}{l}\text { GSS\#2: } \\
\text { Fairness Question }\end{array}$ & $\begin{array}{c}0.679 \\
(0.194)\end{array}$ & & $\begin{array}{l}\text { GSS\#2: } \\
\text { Fairness Question }\end{array}$ & $\begin{array}{c}0.677 \\
(0.468)\end{array}$ \\
\hline $\begin{array}{l}\text { GSS\#3: } \\
\text { Helpfulness Quest. }\end{array}$ & $\begin{array}{r}0.346 \\
(0.210)\end{array}$ & & $\begin{array}{l}\text { GSS\#3: } \\
\text { Helpfulness Question }\end{array}$ & $\begin{array}{r}0.357 \\
(0.480)\end{array}$ \\
\hline
\end{tabular}


Table 2: Frequencies of Failures and Contribution Decisions (number of groups, number of actual contributors)

Round

Number

\begin{tabular}{llll} 
& \% Failures & \multicolumn{2}{r}{ Contributions } \\
1 & $21.79 \%$ & & $71.79 \%$ \\
2 & $16.0 \%$ & $(26,112)$ & \\
& & $62.67 \%$ \\
3 & $15.87 \%$ & $(25,94)$ & \\
& & $(21,79)$ & $62.70 \%$ \\
4 & $14.58 \%$ & & $57.29 \%$ \\
5 & $9.72 \%$ & $(16,55)$ & \\
& & $(12,46)$ & $63.89 \%$ \\
6 & $11.11 \%$ & & $70.37 \%$ \\
& & $(9,38)$ &
\end{tabular}

Nyanga, South Africa

$\begin{array}{ccc}\begin{array}{c}\text { \% Failures } \\ 15.0 \%\end{array} & \begin{array}{c}\text { Contributions } \\ 68.33 \%\end{array} \\ 25.93 \% & (10,41) & \\ & (9,26) & 48.15 \% \\ 13.33 \% & & 56.67 \% \\ 33.33 \% & (5,17) & \\ 16.67 \% & (3,9) & 50.0 \% \\ 33.33 \% & (2,6) & 50.0 \% \\ & (1,4) & 66.67 \%\end{array}$


Table 3: Individual Repayment Decisions--Nyanga and Berd Dependent Variable: Fraction of Times Repaid Divided by Opportunities to Repayt

---OLS Estimations---

Indiv. Repayment:

Variable:

No. of Observations: Intercept

Mean Contribution

from Others

Mean Shocks

Received--Self

Mean Shocks

Received-Others

Knows Others

in Group

Mean Would Loan to each Indiv. in Group

Mean Distance

to Others' Homes

Fraction of Life

Lived in Area

Fraction of Others

in Peer Group/Clan

Average Sender Trust

From Trust Game

Average Receiver

Trustworthiness

GSS\#1:

Trust Question

GSS\#2:

Fairness Question

GSS\#3:

Helpfulness Question

Nyanga Dummy

R-Squared

Adj R-Squared

F-Statistic

F-Signif.

\section{Nyanga, South Africa}

$\mathrm{n}=54$

$1.296 * * * \quad 1.294 * * *$

(0.363)

$-0.539 *$

(0.349)

$-0.111$

(0.276)

$-0.215 *$

(0.138)

0.058

(0.108)

$-0.015$

(0.121)

0.004

(0.018)

$-0.077$

(0.070)

$0.178 * * *$

(0.078)

(0.362)

$-0.496$

(0.349)

$(0.279)$

$-0.198$

0.026

(0.109)

0.036

(0.123)

0.002

(0.018)

$-0.051$

$(0.072)$

(0.078)
$-0.151$

(0.286)

$(0.200)$
Indiv. Repayment:

Berd, Armenia

$\mathrm{n}=151$

$\mathrm{n}=151$

$0.629 * * * \quad 0.621 * * *$

$(0.200) \quad(0.221)$

$-0.256$

$-0.261$

( 0.202)

(0.193)

$0.335 * * *$

(0.141)

$0.347 * * *$

(0.137)

$-0.036$

$-0.036$

(0.046)

$-0.013$

$-0.013$

(0.021)

(0.022)

$0.039 * * *$

$0.038 * * *$

(0.016)

(0.016)

$0.006 * * *$

$0.006 * * *$

(0.003)

(0.003)

0.001

0.001

(0.001)

(0.0009)

$0.183 * * * \quad 0.033$

(0.107)

0.033

(0.108)

0.046

0.061

(0.122)

(0.126)

$\begin{array}{ll}-0.293 & 0.098\end{array}$

0.105

(0.121)

(0.123)

$-0.034$

(0.061)

0.017

(0.061)

0.067

(0.056)

$\begin{array}{llll}0.1882 & 0.2272 & 0.1222 & 0.1326 \\ 0.0439 & 0.0475 & 0.0600 & 0.0509 \\ 1.30 & 1.26 & 1.96 & 1.62 \\ 0.265 & 0.280 & 0.042 & 0.086\end{array}$

$* * * 95 \%$ Significance, $* * 90 \%$ Significance, $* 85 \%$ Significance.

Standard errors are given in parentheses. 


\section{Table 4: Individual Repayment Decisions in Microfinance Game--Berd}

Dependent Variable: Individual Contributes in Round $=1$

---Binary Logit on Pooled Panel Data---

\begin{tabular}{|c|c|c|c|c|c|c|c|}
\hline $\begin{array}{l}\text { Variable: } \\
\text { Number of Observations: } \\
\text { Intercept }\end{array}$ & $\begin{array}{c}\text { Only } \\
\text { Trustors } \\
\mathrm{n}=213 \\
-2.981 \\
(4.780)\end{array}$ & $\begin{array}{c}\text { Only } \\
\text { Trustees } \\
\text { n }=214 \\
-4.789 \\
(4.360)\end{array}$ & $\begin{array}{c}\text { All Rounds } \\
\begin{array}{c}\mathrm{n}=427 \\
-3.335 \\
(3.127)\end{array}\end{array}$ & $\begin{array}{c}\text { Round } 2 \\
\mathrm{n}=126 \\
-12.061 * \\
(8.163)\end{array}$ & $\begin{array}{c}\text { Round } 3 \\
\mathrm{n}=106 \\
-2.630 \\
(8.986)\end{array}$ & $\begin{array}{c}\text { Round } 4 \\
\mathrm{n}=82 \\
-3.059 \\
(8.685)\end{array}$ & $\begin{array}{c}\text { Round 5 } \\
\mathrm{n}=65 \\
-5.935 \\
(8.468)\end{array}$ \\
\hline $\begin{array}{l}\text { Subject Contributed } \\
\text { Period Before }\end{array}$ & $\begin{array}{c}1.936 * * \\
(1.184)\end{array}$ & $\begin{array}{c}1.435 \\
(1.064)\end{array}$ & $\begin{array}{c}1.766 * * * \\
(0.773)\end{array}$ & $\begin{array}{l}3.023 * \\
(2.027)\end{array}$ & $\begin{array}{c}2.077 \\
(2.266)\end{array}$ & $\begin{array}{c}2.956 \\
(2.165)\end{array}$ & $\begin{array}{c}2.744 \\
(2.277)\end{array}$ \\
\hline $\begin{array}{l}\text { Shock to Subject } \\
\text { Period Before }\end{array}$ & $\begin{array}{c}1.452 * * * \\
(0.545)\end{array}$ & $\begin{array}{c}0.770 \\
(0.630)\end{array}$ & $\begin{array}{c}1.131 * * * \\
(0.401)\end{array}$ & $\begin{array}{c}1.096 \\
(1.077)\end{array}$ & $\begin{array}{l}1.412 * \\
(0.993)\end{array}$ & $\begin{array}{l}1.562 * \\
(1.039)\end{array}$ & $\begin{array}{c}3.871 * * * \\
(1.583)\end{array}$ \\
\hline $\begin{array}{l}\text { Shocks to Others in Group } \\
\text { Period Before }\end{array}$ & $\begin{array}{c}-0.373 * \\
(0.247)\end{array}$ & $\begin{array}{c}-0.179 \\
0.236\end{array}$ & $\begin{array}{c}-0.253^{*} \\
(0.165)\end{array}$ & $\begin{array}{l}-0.043 \\
(0.420)\end{array}$ & $\begin{array}{l}-0.053 \\
(0.541)\end{array}$ & $\begin{array}{l}-0.375 \\
(0.386)\end{array}$ & $\begin{array}{l}-0.386 \\
(0.668)\end{array}$ \\
\hline $\begin{array}{l}\text { Contributions by Others } \\
\text { in Group - Period Before }\end{array}$ & $\begin{array}{l}0.0002 \\
(0.001)\end{array}$ & $\begin{array}{l}0.0007 \\
(0.001)\end{array}$ & $\begin{array}{c}0.0005 \\
(0.0009)\end{array}$ & $\begin{array}{c}0.002 \\
(0.002)\end{array}$ & $\begin{array}{l}0.0004 \\
(0.002)\end{array}$ & $\begin{array}{l}0.0004 \\
(0.002)\end{array}$ & $\begin{array}{c}0.001 \\
(0.002)\end{array}$ \\
\hline $\begin{array}{c}\text { Num. of Acquaintances in } \\
\text { Group }\end{array}$ & $\begin{array}{c}0.159 \\
(0.163)\end{array}$ & $\begin{array}{l}-0.161 \\
(0.139)\end{array}$ & $\begin{array}{l}-0.054 \\
(0.099)\end{array}$ & $\begin{array}{l}-0.234 \\
(0.210)\end{array}$ & $\begin{array}{l}-0.231 \\
(0.238)\end{array}$ & $\begin{array}{c}0.179 \\
(0.239)\end{array}$ & $\begin{array}{l}-0.448 * \\
(0.306)\end{array}$ \\
\hline $\begin{array}{l}\text { Num. of Group Members } \\
\text { Subject Would Loan to }\end{array}$ & $\begin{array}{l}0.174^{*} \\
(0.124)\end{array}$ & $\begin{array}{c}0.280 * * * \\
(0.120)\end{array}$ & $\begin{array}{c}0.241 * * * \\
(0.079)\end{array}$ & $\begin{array}{c}0.508 * * * \\
(0.191)\end{array}$ & $\begin{array}{c}0.447 * * * \\
(0.227)\end{array}$ & $\begin{array}{l}-0.080 \\
(0.162)\end{array}$ & $\begin{array}{l}0.353 * \\
(0.227)\end{array}$ \\
\hline $\begin{array}{l}\text { Mean Distance } \\
\text { to Others' Homes }\end{array}$ & $\begin{array}{l}0.045 * \\
(0.030)\end{array}$ & $\begin{array}{l}0.054 * \\
(0.021)\end{array}$ & $\begin{array}{c}0.042 * * * \\
(0.017)\end{array}$ & $\begin{array}{c}0.087 * * * \\
(0.036)\end{array}$ & $\begin{array}{c}0.028 \\
(0.042)\end{array}$ & $\begin{array}{l}-0.005 \\
(0.037)\end{array}$ & $\begin{array}{c}0.100 * * \\
(0.053)\end{array}$ \\
\hline $\begin{array}{l}\text { Fraction of Life } \\
\text { Lived in Area }\end{array}$ & $\begin{array}{c}0.005 \\
(0.008)\end{array}$ & $\begin{array}{c}0.008 \\
(0.008)\end{array}$ & $\begin{array}{l}0.008 * \\
(0.005)\end{array}$ & $\begin{array}{l}0.014 * \\
(0.009)\end{array}$ & $\begin{array}{c}0.005 \\
(0.010)\end{array}$ & $\begin{array}{l}-0.006 \\
(0.013)\end{array}$ & $\begin{array}{c}0.035 * * \\
(0.021)\end{array}$ \\
\hline $\begin{array}{l}\text { Fraction of Others } \\
\text { in Peer Group }\end{array}$ & $\begin{array}{c}0.057 \\
(0.732)\end{array}$ & $\begin{array}{c}0.347 \\
(0.742)\end{array}$ & $\begin{array}{c}0.180 \\
(0.486)\end{array}$ & $\begin{array}{c}0.631 \\
(0.919)\end{array}$ & $\begin{array}{l}-1.041 \\
(1.255)\end{array}$ & $\begin{array}{c}2.192 * * \\
(1.187)\end{array}$ & $\begin{array}{l}-1.218 \\
(1.481)\end{array}$ \\
\hline $\begin{array}{c}\text { GSS\#1: } \\
\text { Trust Question }\end{array}$ & $\begin{array}{l}-0.405 \\
(0.393)\end{array}$ & $\begin{array}{l}-0.175 \\
(0.402)\end{array}$ & $\begin{array}{l}-0.228 \\
(0.263)\end{array}$ & $\begin{array}{l}-0.174 \\
(0.556)\end{array}$ & $\begin{array}{c}0.023 \\
(0.610)\end{array}$ & $\begin{array}{l}-0.070 \\
(0.633)\end{array}$ & $\begin{array}{c}-1.474 * * \\
(0.779)\end{array}$ \\
\hline $\begin{array}{c}\text { GSS\#2: } \\
\text { Fairness Question }\end{array}$ & $\begin{array}{l}0.614 * \\
(0.419)\end{array}$ & $\begin{array}{c}0.192 \\
(0.395)\end{array}$ & $\begin{array}{c}0.261 \\
(0.260)\end{array}$ & $\begin{array}{c}0.637 \\
(0.539)\end{array}$ & $\begin{array}{l}0.879 * \\
(0.598)\end{array}$ & $\begin{array}{r}-1.013 * \\
(0.663)\end{array}$ & $\begin{array}{l}0.441 \\
(0.805)\end{array}$ \\
\hline $\begin{array}{c}\text { GSS\#3: } \\
\text { Helpfulness Question }\end{array}$ & $\begin{array}{c}0.418 \\
(0.386)\end{array}$ & $\begin{array}{c}0.174 \\
(0.416)\end{array}$ & $\begin{array}{c}0.266 \\
(0.267)\end{array}$ & $\begin{array}{c}0.116 \\
(0.525)\end{array}$ & $\begin{array}{c}1.504 * * \\
(0.827)\end{array}$ & $\begin{array}{l}-0.092 \\
(0.616)\end{array}$ & $\begin{array}{l}-0.770 \\
(0.726)\end{array}$ \\
\hline $\begin{array}{l}\text { Sender Trust } \\
\text { From Trust Game }\end{array}$ & $\begin{array}{c}0.137 \\
(0.736)\end{array}$ & & & & & & \\
\hline $\begin{array}{l}\text { Receiver Trustworthiness } \\
\text { From Trust Game }\end{array}$ & & $\begin{array}{c}1.523 * * \\
(0.833)\end{array}$ & & & & & \\
\hline $\begin{array}{c}\text { Likelihood Ratio } \\
p \text {-value }\end{array}$ & $\begin{array}{c}29.4118 \\
0.0057\end{array}$ & $\begin{array}{r}34.4995 \\
0.0010\end{array}$ & $\begin{array}{l}53.4543 \\
<0.0001\end{array}$ & $\begin{array}{c}25.0006 \\
0.0148\end{array}$ & $\begin{array}{c}34.9393 \\
0.0005\end{array}$ & $\begin{array}{c}17.9668 \\
0.1167\end{array}$ & $\begin{array}{c}18.3098 \\
0.1066\end{array}$ \\
\hline
\end{tabular}

$* * * 95 \%$ Significance, $* * 90 \%$ Significance, $* 85 \%$ Significance. Standard errors are given in parentheses. 
Table 5: Group Repayment Decisions

Dependent Variable: Number of Rounds Reach by Group in Microfinance Game, $\mu=3.861$ ---OLS Estimates---

Variable:

Number of Observations: Intercept

Mean Per Period Shocks

Received by Group

Mean Number of Acquaintances in Group

Mean Would Loan to

Other Indivs. in Group

Mean Distance

b/t Members' Homes

Mean Fraction of Life

Lived in Area

Heterogeneity-Fraction

Life Lived in Area

Percent Members

Work After Perestroika

Heterogeneity in

Peer Group/Clan

Sender Trust

From Trust Game

Receiver Trustworthiness

GSS\#1:

Trust Question

GSS\#2:

Fairness Question

GSS\#3:

Helpfulness Question

Nyanga Dummy

R-Squared

Adj R-Squared

F-Statistic

F-Signif.
Group Repayment:

Berd, Armenia

$$
\begin{gathered}
\mathrm{n}=25 \\
10.023 * * *
\end{gathered}
$$

(2.041)

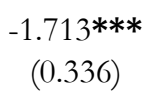

$-1.708 * * *$

(0.387)

0.233

(0.287)

0.021

(0.318)

$-0.063$

(0.048)

$0.075 * * *$

(0.0332)

$-0.116 * * *$

(0.030)

$-1.656 * *$

(0.857)

$-0.473$

(1.07)

0.324

(0.331)

0.040

(0.343)

$-0.053$

(0.0540)

$0.090 * * *$

(0.039)

$-0.122 * * *$

(0.033)

$-1.457 *$

(9.324)

0.423

(1.437)

$-1.851$

(2.172)

2.021

(2.167)

(2.344)

$-2.890$

(2.286)

$-0.971$

(1.765)

2.036

(1.464)
Combined Estimations:

\begin{tabular}{|c|c|c|c|}
\hline $\mathrm{n}=24$ & $\mathrm{n}=35$ & $\mathrm{n}=35$ & $\mathrm{n}=34$ \\
\hline $\begin{array}{c}9.887 * * * \\
(2.720)\end{array}$ & $\begin{array}{c}4.390 * * * \\
(1.725)\end{array}$ & $\begin{array}{c}7.024 * * * \\
(1.989)\end{array}$ & $\begin{array}{c}7.638 * * * \\
(2.448)\end{array}$ \\
\hline $\begin{array}{c}-1.714 * * * \\
(0.413)\end{array}$ & $\begin{array}{c}-1.598 * * * \\
(0.372)\end{array}$ & $\begin{array}{c}-1.721 * * * \\
(0.357)\end{array}$ & $\begin{array}{c}-1.665 * * * \\
(0.400)\end{array}$ \\
\hline $\begin{array}{l}0.609 * \\
(0.370)\end{array}$ & $\begin{array}{c}0.057 \\
(0.308)\end{array}$ & $\begin{array}{c}0.134 \\
(0.308)\end{array}$ & $\begin{array}{c}0.013 \\
(0.346)\end{array}$ \\
\hline $\begin{array}{c}0.033 \\
(0.389)\end{array}$ & $\begin{array}{c}0.677 * * * \\
(0.331)\end{array}$ & $\begin{array}{c}0.433 \\
(0.334)\end{array}$ & $\begin{array}{c}0.448 \\
(0.348)\end{array}$ \\
\hline $\begin{array}{c}-0.038 \\
(0.0515)\end{array}$ & $\begin{array}{c}0.016 \\
(0.053)\end{array}$ & $\begin{array}{c}-0.018 \\
(0.053)\end{array}$ & $\begin{array}{l}-0.023 \\
(0.058)\end{array}$ \\
\hline \multicolumn{4}{|l|}{$\begin{array}{l}0.067^{*} \\
(0.041)\end{array}$} \\
\hline $\begin{array}{c}-0.097 * * * \\
(0.035)\end{array}$ & & $\begin{array}{c}-0.043 * * * \\
(0.018)\end{array}$ & $\begin{array}{c}-0.051 * * * \\
(0.022)\end{array}$ \\
\hline \multicolumn{4}{|l|}{$\begin{array}{c}-1.630 * * \\
(0.892)\end{array}$} \\
\hline $\begin{array}{c}0.775 \\
(1.669)\end{array}$ & & $\begin{array}{l}-0.952 \\
(1.090)\end{array}$ & $\begin{array}{l}-1.193 \\
(1.248)\end{array}$ \\
\hline $\begin{array}{l}-2.515 \\
(2.211)\end{array}$ & & & $\begin{array}{c}0.924 \\
(1.810)\end{array}$ \\
\hline $\begin{array}{c}2.600 \\
(2.344)\end{array}$ & & & $\begin{array}{l}-1.488 \\
(1.648)\end{array}$ \\
\hline
\end{tabular}
Berd and Nyanga 


\section{Appendix: Results of Trust Games}

(A.)

$$
\begin{aligned}
& \text { Sender's Trust } \\
& \text { (\% Amount Sent to } \\
& \text { Receiver) } \\
& 0 \\
& (0-25 \%] \\
& (25 \%-50 \%) \\
& 50 \% \\
& (50 \%-75 \%] \\
& (75 \%-100 \%) \\
& 100 \% \\
& \text { Num. Obs. }
\end{aligned}
$$

\section{Table A-1}

\section{- Berd -}

Equal Initial

All Games

25.0

30.8

29.5

7.1

7.7

156

Amounts

20.8

35.1

28.6

10.4

5.2

77

\section{Nyanga}

Unequal Initial

Amounts

55.0

21.7

20.0

3.3

60
(B.)

\section{Receiver's}

Trustworthiness

(\% Amount Sent

to Receiver)

0

$(0-25 \%]$

$(25 \%-50 \%)$

$50 \%$

(50\% - 75\%]

$(75 \%-100 \%)$

$100 \%$

Num. Obs.
(C.)

\section{Receiver's \\ Trustworthiness}

(\% Amount Sent to Receiver)

$$
0
$$

$$
(0-25 \%]
$$$$
\text { (25\%- 50\%) }
$$$$
50 \%
$$

(50\%- 75\%]

$(75 \%-100 \%)$

$100 \%$

Num. Obs.

\begin{tabular}{ccccccc}
\multicolumn{7}{c}{ All Gard - } \\
\multicolumn{7}{c}{} \\
$(0-$ & $(25 \%-$ & \multicolumn{7}{c}{ Bames } & \\
$25 \%$ & $50 \%)$ & $50 \%$ & $75 \%]$ & $100 \%)$ & $100 \%$ & Obs. \\
- & - & - & - & - & - & - \\
- & 28.2 & 46.2 & 20.5 & - & 5.1 & 39 \\
29.2 & 39.6 & 10.4 & 8.3 & 8.3 & 4.2 & 48 \\
26.1 & 39.1 & - & 17.4 & 13.0 & 4.4 & 46 \\
- & - & - & - & - & - & - \\
63.6 & 18.2 & - & - & 18.2 & - & 11 \\
16.7 & 50.0 & 33.3 & - & - & - & 12 \\
35 & 56 & 27 & 20 & 12 & 6 & 156
\end{tabular}

Num. 48 12 56 
(D.)

Receiver's

Trustworthiness

(\% Amount Sent
to Receiver)
0
$(0-25 \%]$
$(25 \%-50 \%)$
$50 \%$
$(50 \%-75 \%]$
$(75 \%-100 \%)$
$100 \%$
Num. Obs.

\section{(E.)}

Receiver's

Trustworthiness

$$
\begin{gathered}
\text { (\% Amount Sent } \\
\text { to Receiver) } \\
0 \\
(0-25 \%] \\
(25 \%-50 \%) \\
50 \% \\
(50 \%-75 \%] \\
(75 \%-100 \%) \\
100 \%
\end{gathered}
$$

Num. Obs.

\section{Unequal Initial Amounts}

0
-
-
-
-
-
-
-
0

$(0-$
$25 \%]$
-
-
19.1
41.7
-
33.3
-
15

$(25 \%-$
$50 \%)$
-
21.7
42.9
25.0
-
-
75.0
26

$\%$ Amount Sent Back to Sender)

$\begin{array}{lll}50 \% & (50 \%- & (75 \%- \\ - & 75 \%] & 100 \%)\end{array}$

$\begin{array}{cc}100 \% & \text { No. Obs. } \\ - & 0 \\ - & 23 \\ - & 21 \\ 8.3 & 24 \\ - & 0 \\ - & 3 \\ - & 8 \\ 2 & 79\end{array}$

\section{- Nyanga - \\ Unequal Initial Amounts All Games \\ ( $\%$ Amount Sent Back to Sender)}

$\begin{array}{cccccccc} & (0- & (25 \%- & & (50 \%- & (75 \%- & & \text { No. } \\ 0 & 25 \%] & 50 \%) & 50 \% & 75 \%] & 100 \%) & 100 \% & \text { Obs. } \\ - & - & - & - & - & - & - & - \\ 12.9 & 19.35 & 61.29 & - & 6.45 & - & - & 31 \\ - & 38.46 & 15.38 & 30.77 & - & 15.38 & - & 13 \\ - & - & - & - & - & - & - & - \\ 33.33 & 33.33 & 16.67 & - & 16.67 & - & - & 12 \\ - & - & - & 100 & - & - & - & 2 \\ - & - & - & - & - & - & - & 0 \\ 8 & 15 & 23 & 6 & 4 & 2 & 0 & 58\end{array}$

